\title{
Automated method for the estimation of serum protein-bound iodine following alkaline incineration
}

\author{
S. G. WELSHMAN, J. F. BELL, AND G. MCKEE \\ From the Laboratories, Belfast City Hospital, Belfast (Northern Ireland)
}

SYNOPSIS A method is described for the estimation of serum protein-bound iodine using alkaline incineration and an automated technique for the estimation of iodine in the ash. Pretreatment of the serum with an anion exchange resin avoids the need for precipitation and washing of the protein. The method is accurate, reproducible, and simple to perform.

A detailed investigation of the alkaline ashing method for the determination of serum proteinbound iodine was described by Foss, Hankes, and Van Slyke (1960). Their procedure included precipitation and washing of the serum protein, incineration of the protein with potassium hydroxide, and the colorimetric estimation of the inorganic iodine in the ash by its quantitative effect on the reduction of ceric sulphate with arsenious acid.

A method for the automation of the final colorimetric analysis was produced by the Technicon Instruments Company and papers have been published describing various modifications of this procedure by Widdowson and Northam (1963) and Benotti and Benotti (1963). However, these methods are only suitable for the analysis of samples after chloric acid digestion. Stevens and Levandoski (1963) described an AutoAnalyzer technique for the estimation of iodine in alkaline ash which involved the addition of a known excess of iodine to each sample. The method was considered to be too complicated, insensitive, and slow for the number of estimations normally carried out in a large laboratory.

This communication describes a simple method for the estimation of serum protein-bound iodine using the alkaline incineration technique of Foss $e t$ al. (1960) and an AutoAnalyzer procedure for the estimation of iodine in the ash which is rapid and reproducible. As an anion exchange resin is used to remove any inorganic iodine from the serum, precipitation and washing of the serum protein was found to be unnecessary.

\section{APPARATUS}

1 Pyrex test tubes, rimless $\mathrm{M} / \mathrm{W}, 16 \times 125 \mathrm{~mm}$. (cat. no. $1626 / 10$ ).

2 Metal rack to hold 36 incineration tubes and the special handles are constructed on the same principle as described by Foss et al. (1960).

\section{REAGENTS}

1 'Permutit' De-Acidite FF anion exchange resin.

2 POTASSIUM HYDROXIDE, 2N Dissolve approximately $70 \mathrm{~g}$. of potassium hydroxide pellets in 1 litre of water. Standardize the solution with $\mathrm{N}$ sulphuric acid and adjust the concentration to $2 \mathrm{~N}$ with water.

3 CERIC AMmONium SUlPhate SOlution Dissolve $16 \mathrm{~g}$. of ceric ammonium sulphate in about $500 \mathrm{ml}$. of water. Add $200 \mathrm{ml}$. of concentrated sulphuric acid, mix thoroughly, and make up to 5 litres with water.

4 SODIUM ARSENITE SOLUTION Dissolve $6 \mathrm{~g}$. of arsenious oxide in $30 \mathrm{ml}$. of $\mathrm{N}$ sodium hydroxide and $100 \mathrm{ml}$. of water. Heat gently to dissolve and make up to 5 litres with water.

5 ACID REAGENT Add $390 \mathrm{ml}$. of concentrated sulphuric acid to $500 \mathrm{ml}$. of water. Cool to room temperature and add $110 \mathrm{ml}$. of concentrated hydrochloric acid. Make up to 1 litre with water.

6 ACID DILUENT Dilute the acid reagent 1 in 5 with water.

7 BLANK REAGENT To $600 \mathrm{ml}$. of water add $200 \mathrm{ml}$. of $2 \mathrm{~N}$ potassium hydroxide and $200 \mathrm{ml}$. acid reagent. 


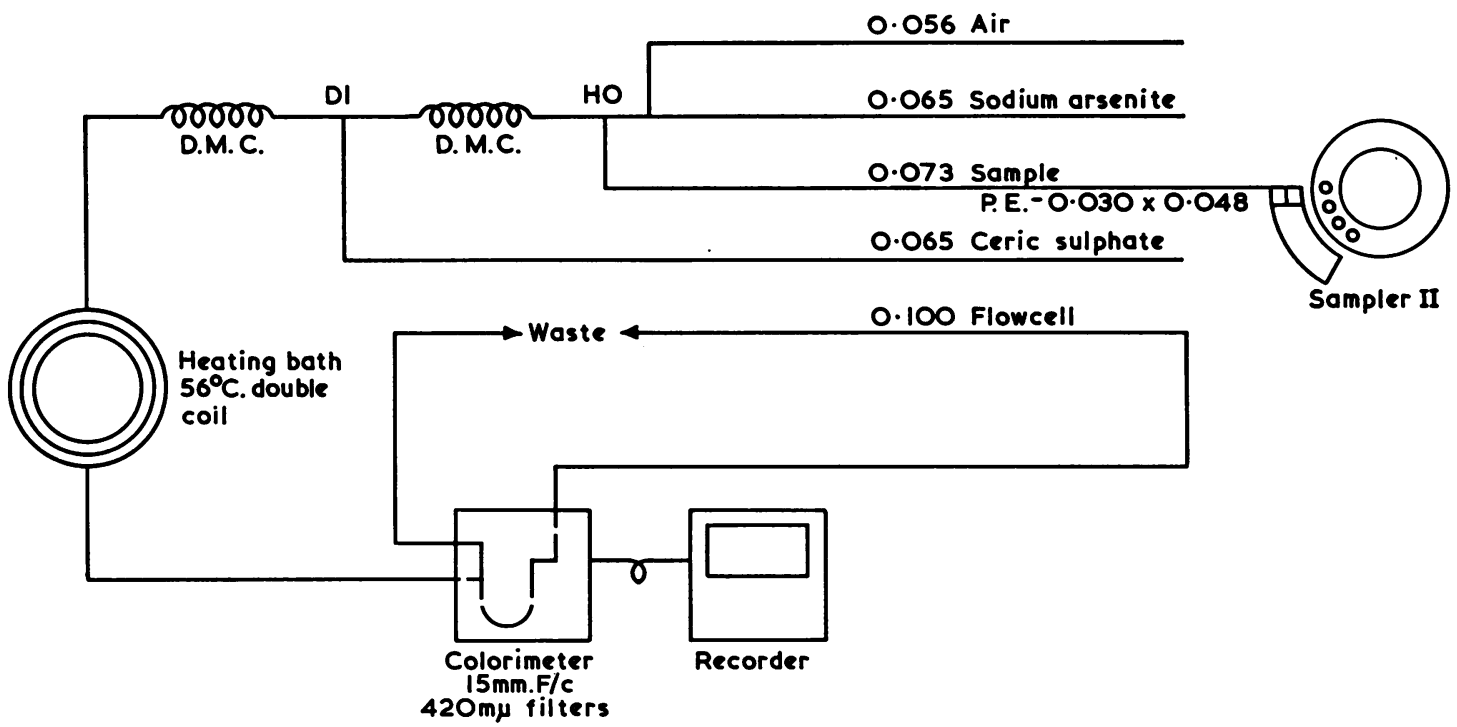

FIG. 1. Flow diagram for the estimation of iodine by AutoAnalyzer after alkaline incineration.

8 STOCK IODIDE SOLUTION A (20 MG. IODINE PER 100 ML.) Dissolve $262 \mathrm{mg}$. of potassium iodide in water and dilute to 1 litre.

9 STOCK IODIDE SOLUTION B (200 $\mu$ G. IODINE PER 100 ML.) Dilute $10 \mathrm{ml}$. solution A to 1 litre with water.

10 STOCK STANDARD (EQUivalent TO $100 \mu \mathrm{G}$. IODINE PER $100 \mathrm{ML}$.) Dilute $10 \mathrm{ml}$. of iodide solution B with about $40 \mathrm{ml}$. of water, add $20 \mathrm{ml}$. of $2 \mathrm{~N}$ potassium hydroxide solution, and $20 \mathrm{ml}$. of acid reagent. Make up to $100 \mathrm{ml}$. with water.

11 WORKING STANDARDS Dilute the stock standard (equivalent to $100 \mu \mathrm{g}$. iodine per $100 \mathrm{ml}$.) with blank reagent to give a series of standards equivalent to 5,10 , 15 , and $20 \mu \mathrm{g}$. iodine per $100 \mathrm{ml}$. The standards are stable for at least four weeks if stored in amber bottles.

Use double-deionized water for the preparation of all solutions and standards.

\section{PROCEDURE}

Mix the serum thoroughly with a little of the anion exchange resin (approximately $0.2 \mathrm{~g}$.) to remove any inorganic iodine. Centrifuge the serum and transfer $1 \mathrm{ml}$. to a Pyrex incineration tube, add $1 \mathrm{ml}$. of $2 \mathrm{~N}$ potassium hydroxide, mix thoroughly and place the tubes in an oven at $115^{\circ} \mathrm{C}$. overnight (at least 18 hours). When the tubes are completely dry transfer them to a cool muffle furnace and close the door. Allow the temperature to rise to $620^{\circ} \mathrm{C}$. When the oven has reached the required temperature open the door for about 30 seconds: repeat this procedure at 20-minute intervals for one hour. Remove the tubes and allow to cool to room temperature. Gently add $5 \mathrm{ml}$. of acid diluent, mix thoroughly, and centrifuge at 2,000 r.p.m. for 10 minutes. Without delay decant a portion of each supernatant into an AutoAnalyzer sample cup and estimate the iodine in the solution using the AutoAnalyzer system shown in Figure 1. To obtain the correct base line equivalent to $0 \mu \mathrm{g}$. of iodine per $100 \mathrm{ml}$, pump the blank reagent through the sample line while the other reagents are passing through their respective flow tubes. The rate of determination is 60 samples per hour.

\section{RESULTS AND DISCUSSION}

Ten samples of a normal and abnormal Hyland control serum were analysed by the above procedure. The normal control serum $(5.0 \mu \mathrm{g}$. iodine per 100 ml.) gave a mean result of $4.8 \mu \mathrm{g}$. per $100 \mathrm{ml}$. and the abnormal control serum $(10.6 \mu \mathrm{g}$. iodine per $100 \mathrm{ml}$.) gave a mean result of $10.8 \mu \mathrm{g}$. per $100 \mathrm{ml}$. The standard deviations for the normal and abnormal controls were 0.12 and 0.24 respectively. The AutoAnalyzer record of this investigation is shown in Figure 2. Recovery experiments were carried out by adding a solution of sodium thyroxine to pooled serum corresponding to an increase of $10 \mu \mathrm{g}$. of iodine per $100 \mathrm{ml}$. The average recovery from 10 separate estimations was $95 \%$. Resin treatment was found to be effective in removing any inorganic iodide likely to be present in sera. Using the recommended method the anion exchange resin absorbed $0.75 \mu \mathrm{g}$. of iodine per ml. of serum. A pooled serum from blood donors was analysed using both resin treatment and protein precipitation methods. The 


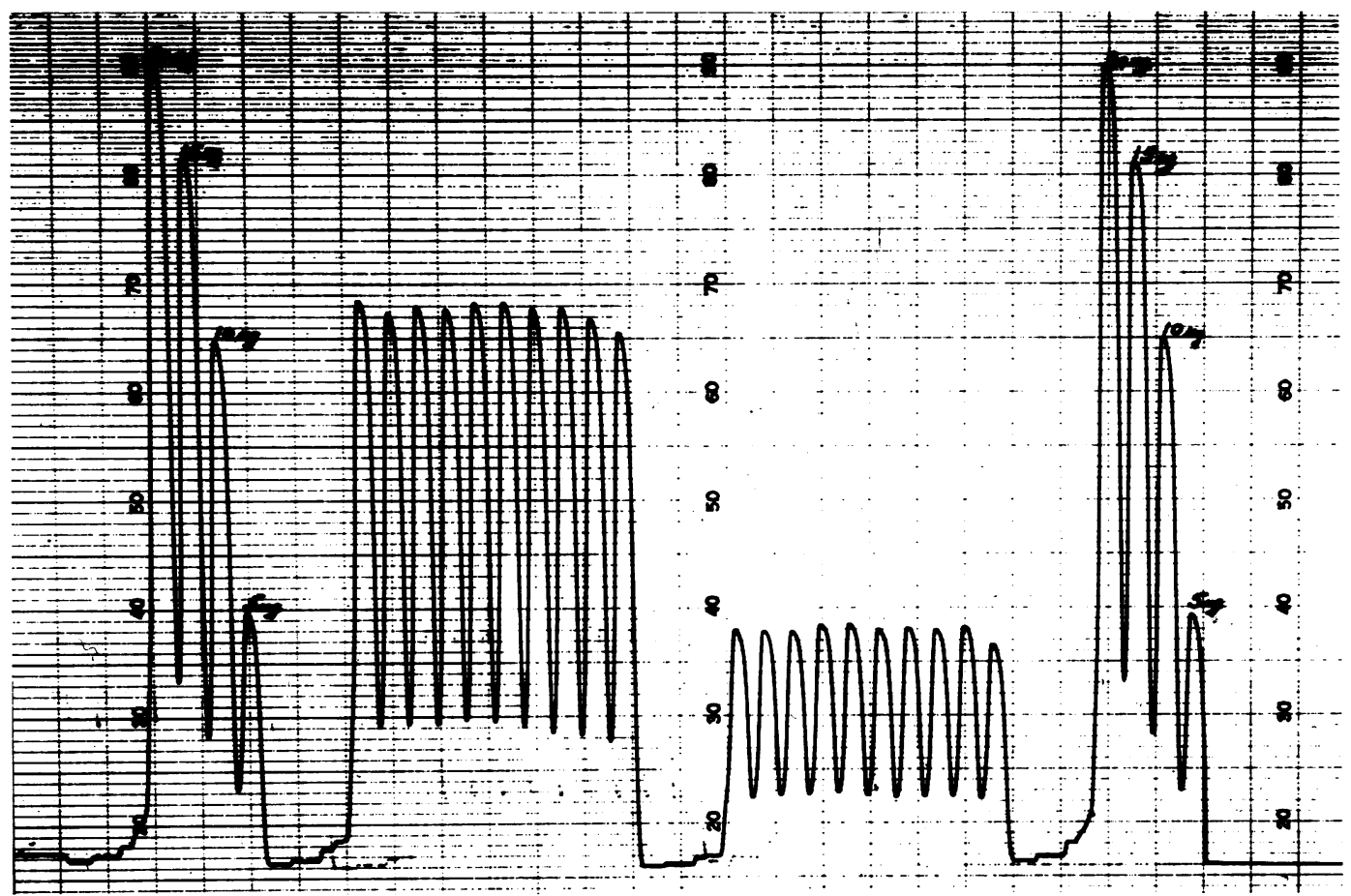

FIG. 2. Recorder chart of 10 protein-bound iodine estimations of a normal control serum $(5.0 \mu \mathrm{g} . / 100 \mathrm{ml}$.$) and an$ abnormal control serum $(10 \cdot 6 \mu g . / 100 \mathrm{ml}$.).

mean result of 30 estimations using the resin technique was $4.4 \mu \mathrm{g}$. per $100 \mathrm{ml}$. (standard deviation 0.08 ) and $4.6 \mu \mathrm{g}$. per $100 \mathrm{ml}$. (standard deviation $0 \cdot 15$ ) when iodine is removed by precipitation and washing.

The possibility of iodine loss during the addition of the acid reagent to the alkaline ash was investigated. Contrary to the findings of Foss et al. (1960) the amount of iodine lost during the vigorous evolution of carbon dioxide was negligible.

After the acid reagent is added to the ash, the supernatant is immediately transferred to the sample cup and analysed. If the acid solution remains in the incineration tubes the iodide concentration is slowly reduced. The reason for this effect is unknown but is possibly due to adsorption of iodine on the etched surface of the tubes.
In the AutoAnalyzer technique the carry-over contamination from the $20 \mu \mathrm{g}$. per $100 \mathrm{ml}$. standard was less than $0.2 \mu \mathrm{g}$. per $100 \mathrm{ml}$. It was therefore unnecessary to alternate the test samples with blank solutions.

The semi-automated procedure allows at least 180 specimens, divided into five batches, to be estimated by one technician in five half-days. If a second rack for incineration tubes is used this volume of work can be doubled without any appreciable increase in total working time.

\section{REFERENCES}

Benotti, J., and Benotti, N. (1963). Clin. Chem., 9, 408.

Foss, O. P., Hankes, L. V., and Van Slyke, D. D. (1960). Clin. chim. Acta, 5, 301.

Stevens, C. O., and Levandoski, N. G. (1963). Clin. Chem., 9, 400.

Widdowson, G. M., and Northam, B. E. (1963). Clin. chim. Acta, 8, 636. 